\title{
Předběžný antropologický rozbor kosterních pozůstatků z kruhového objektu (střední doba bronzová) z Nymburka (Česká republika)
}

\author{
Petra Beran-Cimbůrková \\ Ústav archeologické památkové péče středních Čech, Praha, Nad Olšinami 3/448, 10000 Praha10 \\ Ústav antropologie Př́rodovědecké fakulty Masarykovy univerzity, Vinařská 5, 60300 Brno
}

\author{
PRELIMINARY ANTHROPOLOGICAL ANALYSIS OF SKELETAL REMAINS FOUND IN A CIRCULAR OBJECT \\ (MIDDLE BRONZE AGE) FROM NYMBURK (CZECH REPUBLIC)
}

\begin{abstract}
Skeletal material was obtained during the rescue archaeological excavation (the city ring road), which took place in 2009 in Nymburk. At the site were found 10 graves: 8 graves were dated back to the Middle Bronze Age and 2 to the Hallstatt period (Bylany culture). This analysis focuses only on the funerals in a circular object, which was dated to the Middle Bronze Age. In the circular object were found seven graves (one with two individuals in one grave) a total of seven human individuals in six graves (one grave contained only animal bone). The material was unearthed by author. Preservation of human bones varied, but generally increased with the depth of deposit. During the processing of the material were used standard morphometric and morphoscopic methods. Determination of sex showed 3 females, 2 males and 2 not identified individuals (according to DNA analysis more males). Age at death of 7 individuals covered the range from 12 to 50 years $(12-14,14-16,16-18,17-20,30-40,35-40,30-50$ years). Stature was estimated in one adult male (a very high stature) and one adolescent female (very high stature). In 2 adults stature is not determinable and the remaining three individuals were immature. From the anatomical varieties there was an interesting finding of sacralised first coccygeal vertebra of an adult male (object 359). On the left clavicle of the same individual was found the costoclavicular fossa, which is related to excessive load of costoclavicular ligament. No significant pathological changes were recorded. There were just fine and medium dental calculus on the labial surface of upper and lower incisors (in 5 individuals) and Schmorl's nodes on the bottom of the terminal area of Th4-Th7 (spondylosis deformans) on the skeleton of the adult male (object 359). There were no human bones in the grave in object 379 , only a fragment of os coxae of larger animal.
\end{abstract}

KEY WORDS Middle Bronze Age; grave; burial; determination of sex; estimation of age and stature

\begin{abstract}
ABSTRAKT Kosterní materiál byl získán při záchranném archeologickém výzkumu (silniční obchvat města), který proběhl v roce 2009 v Nymburce. Na lokalitě bylo nalezeno celkem 10 hrobů: 8 hrobů je datováno do střední doby bronzové a 2 hroby do doby halštatské (bylanská kultura). Tento rozbor je zaměřen pouze na pohřby z kruhového objektu (objekt 240), který byl datován do střední doby bronzové. V kruhovém objektu bylo nalezeno 7 hrobů ( $\mathrm{z}$ toho jeden dvojhrob), celkem tedy 7 lidských jedinců v 6 hrobech (jeden hrob obsahoval pouze zvírecí kost). Materiál byl vyzvednut autorkou. Zachovalost kostí se u jednotlivých hrobů lišila, ale obecně rostla s hloubkou uložení. Při zpracování materiálu byly použity standardní morfometrické a morfoskopické metody. Výsledky analýzy ukázaly ženské pohlaví u 3 jedincủ, mužské u 2 a nejisté (spíše mužské) u 2 pohřbených jedinců. Dožitý věk všech 7 jedinců pokrýval rozmezí 12 až 50 let (12-14, 14-16, 16-18, 17-20, 30-40, 35-40, 30-50 let). Výška postavy byla určitelná u jednoho dospělého muže (velmi vysoká výška postavy) a u jedné dospívající ženy (velmi vysoká výška postavy) u 2 dospělých jedinců nebyla výška postavy určitelná a zbylí 3 jedinci byli nedospělí. Z anatomických variet je zajímavý nález sakralizovaného prvního kostrčního obratle u dospělého muže (objekt 359). Na levé klíční kosti téhož jedince byla nalezena fossa costoclavicularis (impressio ligamenti costoclavicularis). Nebyly zachyceny žádné výrazné patologické změny. Vyskytoval se pouze slabý a střední zubní kámen na labiální ploše horních i dolních řezáků (u 5 jedinců) a Schmorlovy uzly na dolní terminální ploše Th4 až Th7 (pravděpodobně spondylosis deformans) u dospělého muže (objekt 359). V hrobě v objektu 379 nebyly nalezeny žádné lidské kosti, pouze zlomek pánevní kosti většího zvířete.
\end{abstract}

KLÍČOVÁ SLOVA střední doba bronzová; hrob; pohřeb; základní antropologické určení 


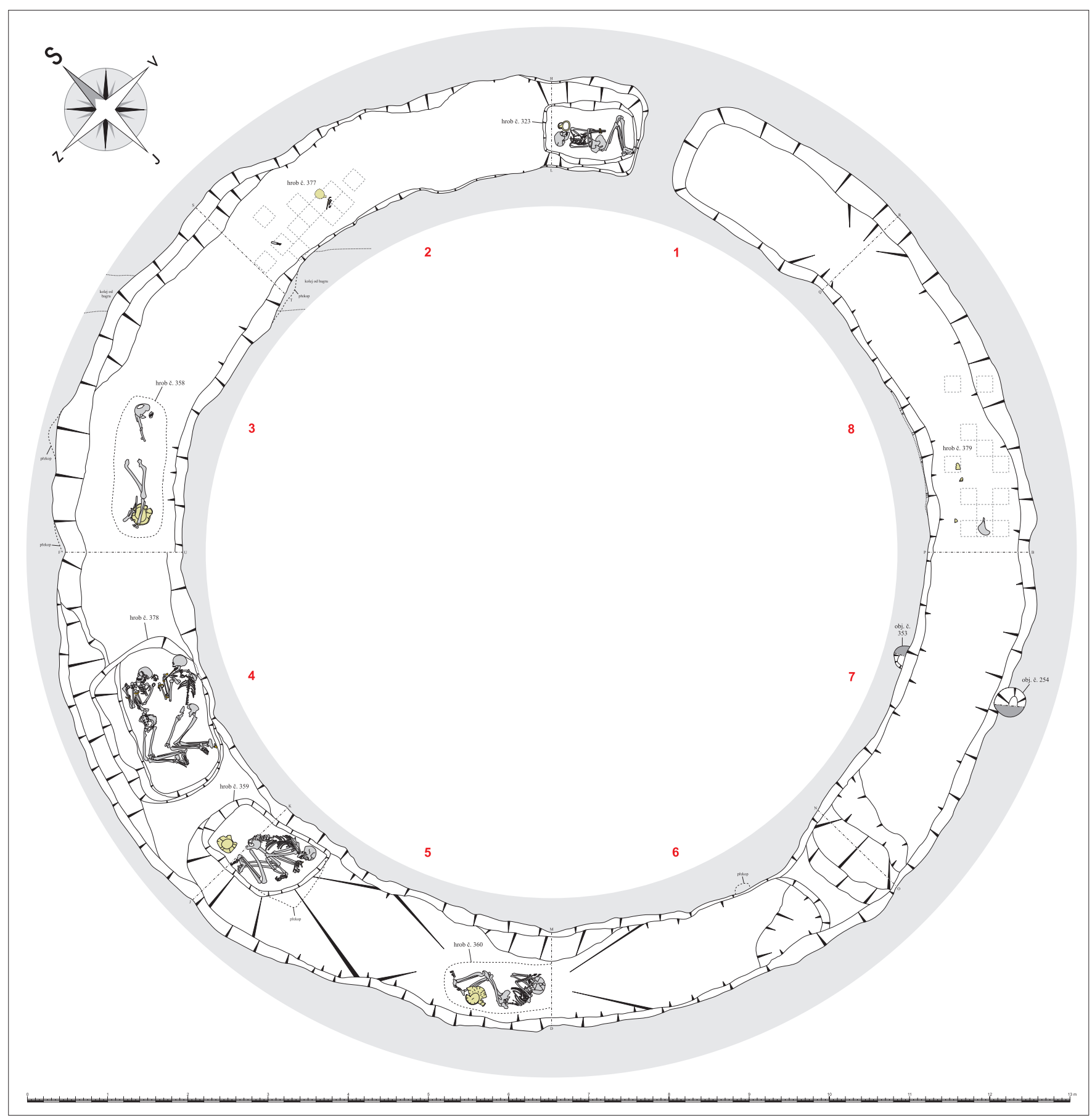

Obr. 1. Nymburk, objekt 240. Kresba: archiv ÚAPPSČ.

\section{ÚVOD}

Zpracovávaný kosterní materiál byl získán př̀ záchranném archeologickém výzkumu (silniční obchvat města), který proběhl v roce 2009 v Nymburce. Výzkum prováděl Ústav archeologické památkové péče středních Čech a byl veden Lukášem Balounem. Na zkoumané lokalitě bylo nalezeno celkem 10 hrobů: 8 hrobů je datováno do střední doby bronzové a 2 hroby do doby halštatské (bylanská kultura). Mezi mnoha objekty byl nalezen také zajímavý kruhový objekt (objekt 240) o vněj- ším průměru 12 metrů, hloubce $30-60 \mathrm{~cm}$ a šírce zahloubené obvodové části 1-1,5 metru, který se po skrývce plochy jevil jako kruhový př́kop s jasným vstupem na SV straně a dalšími dvěma vstupy na jižní a západní straně (obr. 1). Uvnitř kruhu nebyl nalezen žádný další objekt. Některé pohřby (objekt 323, 359,378 ) byly zapuštěny pod úroveň dna kruhového př́kopu, zbylé pohřby (objekt $358,360,377,379$ ) byly uloženy na dno př́kopu. Hroby byly bohatě vybaveny bronzovými šperky (náramky, jehlice, prsteny, drobný jantarový korálek a bronzové vlasové ozdoby) a nádobami. V rámci ČR se jedná o unikátní nález pohřbů v takovémto kruhovém objektu. 


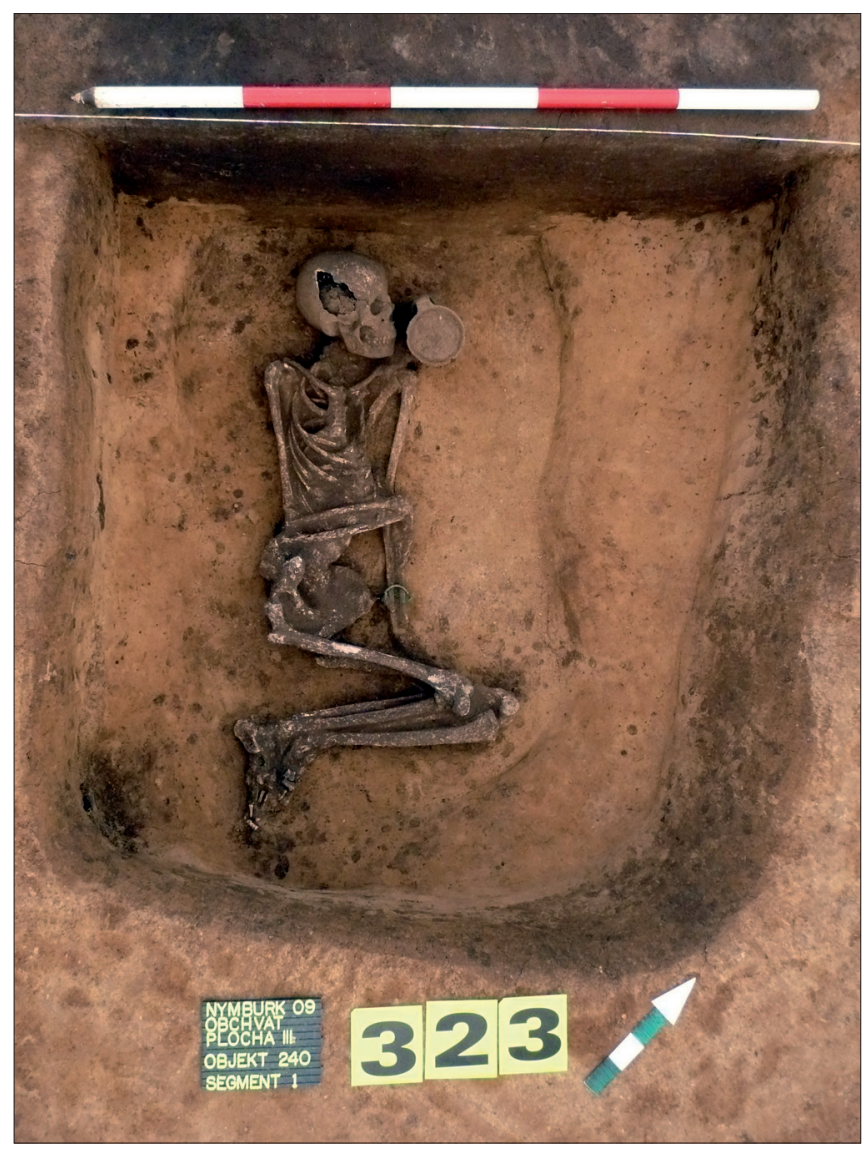

Obr. 2. Nymburk, objekt 323. Celkový pohled na nálezovou situaci.

\section{MATERIÁL}

Tento rozbor je zaměřen pouze na pohřby z kruhového objektu (obr. 1), který byl datován do střední doby bronzové. $\mathrm{V}$ kruhovém objektu bylo nalezeno 7 hrobů ( $\mathrm{z}$ toho jeden dvojhrob) celkem tedy 7 lidských jedinců $v 6$ hrobech (jeden hrob obsahoval pouze zviŕecí kost). Zachovalost kostí se u jednotlivých hrobů značně lišila, ale obecně rostla s hloubkou uložení $(25-80 \mathrm{~cm})$. Materiál byl v terénu vyzvednut autorkou.

\section{METODY}

Při zpracování materiálu byly použity standardní morfometrické a morfoskopické metody. K určování pohlaví dospělých na pánevní kosti byla použita metoda dle Acsádiho a Nemeskériho (Acsádi - Nemeskéri 1970), na pažní a stehenní kosti dle Černého a Komendy (Černý - Komenda 1980, 147-167) a na lebce dle Novotného (Novotný et al. 1993, 71-88) a Acsádiho a Nemeskériho (Acsádi - Nemeskéri 1970). Věk dospělých jedinců byl určován dle Lovejoye (Lovejoy 1985, 47-56). U nedospělých jedinců bylo pohlaví určováno dle Schutkowského (Schutkowski 1993, 199-205). Věk nedospělých jedinců byl hodnocen dle vývoje chrupu dle Ubelakera (Ubelaker 1978), dle délky dlouhých kostí končetin dle Stloukala a Hanákové (Stloukal - Hanáková 1978, 53-69) a dle celkové maturace kostry dle príručky Juvenile Osteology (Schaefer et al. 2009, 337-355). Výška postavy byla určová-

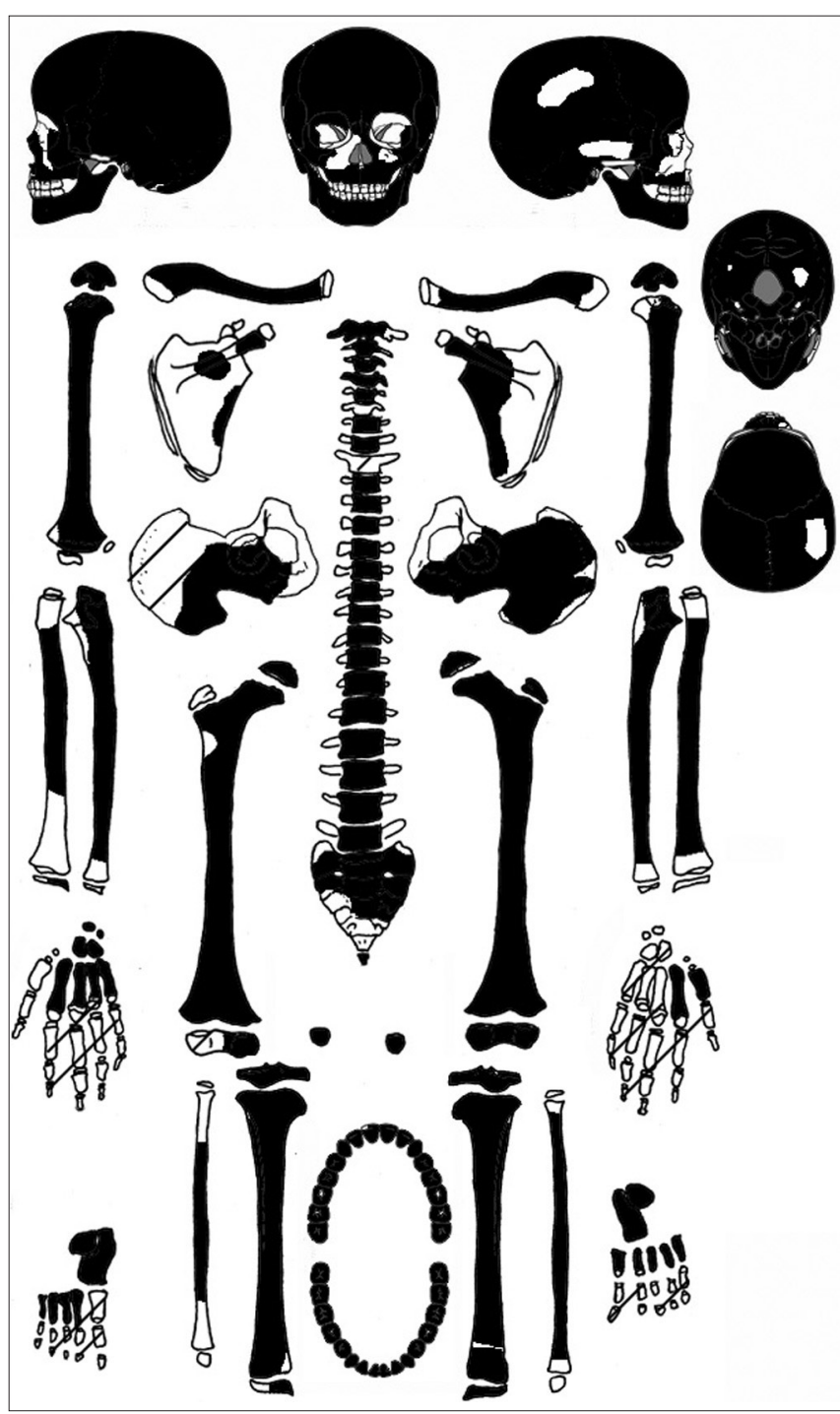

Obr. 3. Nymburk, objekt 323. Schematický nákres zachovalosti a kompletnosti skeletu.

na pouze u dospělých, metodou dle Sjøvolda (Sjøvold 1990, 431-447). Kategorizace výšky postavy byla provedena podle Martina a Sallera (Martin - Saller 1957, 324). Anatomické variety byly hodnoceny dle přehledu uvedeného v prríručce Antropologie (Stloukal et al. 1999, 125-151). Patologické nálezy byly určovány dle Horáčkové - Strouhala - Vargové (2004), Aufderheideho a Rodrígueze-Martina (Aufderheide - Rodríguez-Martin 1998) a Ortnera a Putschara (Ortner - Putschar 1985). Předběžnou genetickou analýzu DNA (extrakcí mikromnožství biologického materiálu), na zjišš̌ní pohlaví a př́íbuznosti jedinců, provedl Ivan Mazura.

\section{VÝSLEDKY}

Objekt 323 (obr. 2, obr. 3)

Popis nálezové situace - hloubka $45-50 \mathrm{~cm}$; kostra nedospělého jedince ležící na levém boku (SZ-JV), pravá horní končetina pokrčená v lokti, levá natažená podél těla, dolní končetiny 


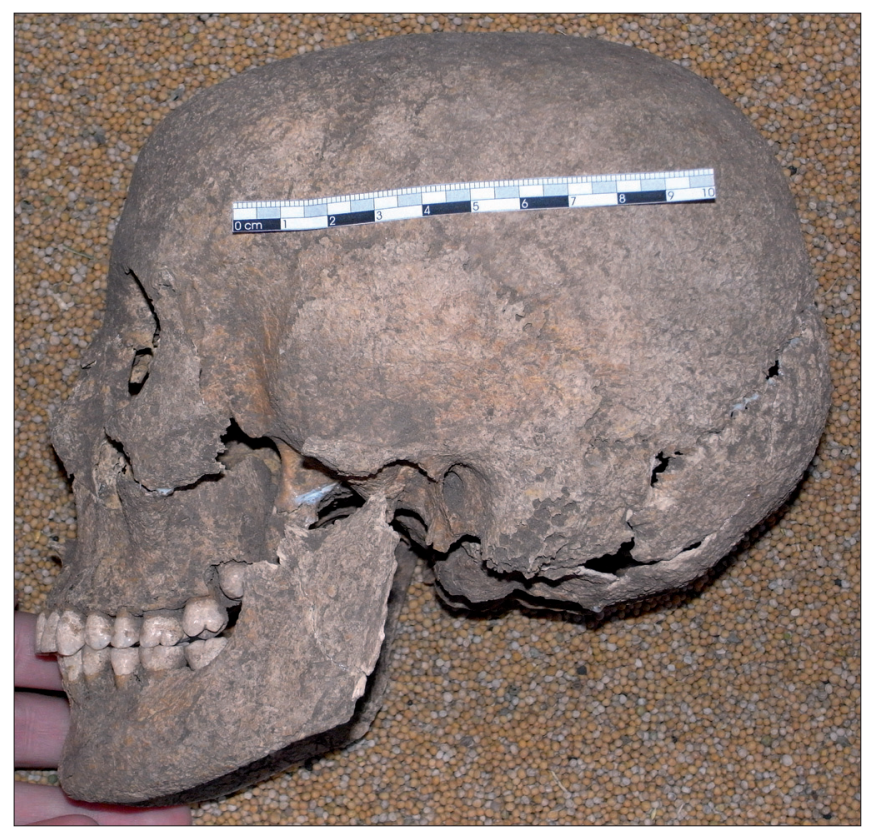

Obr. 4. Nymburk, objekt 323. Lebka (pohled v norma lateralis sinistra).

pokrčené v kolenou. Následkem tafonomických procesů ležel trup na zádech. Inventář hrobu zahrnoval keramickou nádobu (před obličejem) a bronzový náramek na levém předloktí a další bronzový náramek u nádoby.

Lebka - velmi dobře zachovaná (obr. 4). Až na oboustranné poškození těla horní čelisti a několik chybějících fragmentů z pravostranné temenní kosti byla lebka bez poškození. Spodina lebeční byla výborně zachována. Trvalá dentice byla kompletní, pouze žádná třetí stolička nebyla ještě plně prořezána. Na genetickou analýzu byla dána pravostranná horní druhá stolička.

Osový skelet - dobře zachovaný. Z obratlů chyběl pouze C6 a krční i hrudní obratle byly částečně poškozeny. Bederní obratle byly téměř nepoškozené. Z k řrižové kosti byly zachovány S1až S3. Dále byl nalezen první kostrční obratel. Obě první žebra měla lehce poškozený sternální konec, zbylá žebra byla fragmentarizována.

Horní končetiny - dobře zachované. Obě klíční kosti byly zachovány téměř celé (oba konce chybí). Dále byl nalezen z pravé lopatky zlomek hřebenu, nadpažek a část laterálního okraje. Z pravé strany byla zachována kloubní jamka, nadpažek, polovina hřebenu a laterální okraj. Pažní kosti byly zachovány, až na drobná poškození konců, celé. Nepřirostlá hlavice kosti pažní byla rovněž nalezena na obou stranách. Pravostranná kost loketní a vřetenní byla hưře zachována než levostranná (vlevo byly kosti v místě náramku zabarvené oxidy kovů). Z kostí ruky se dochovala pouze pravostranná kost lod'kovitá, poloměsíčitá, hlavatá a hákovitá a druhá až pátá kost záprstní. Z levé strany byly identifikovány pouze první a druhá kost záprstní. Rovněž byly nalezeny články prstů z proximální a mediální řady.

Dolní končetiny - dobře zachované. Z pánve byl zachován pouze zlomek $s$ velkým sedacím zářezem $\mathrm{z}$ pravé strany a $\mathrm{z}$ levé strany byla kost pánevní lépe zachována, ale poškoze-

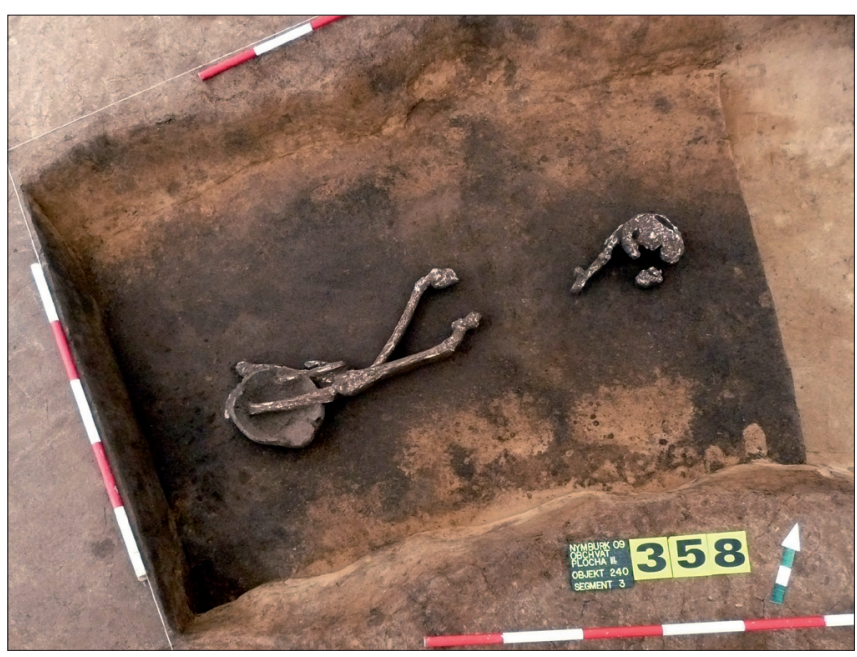

Obr. 5. Nymburk, objekt 358. Celkový pohled na nálezovou situaci.

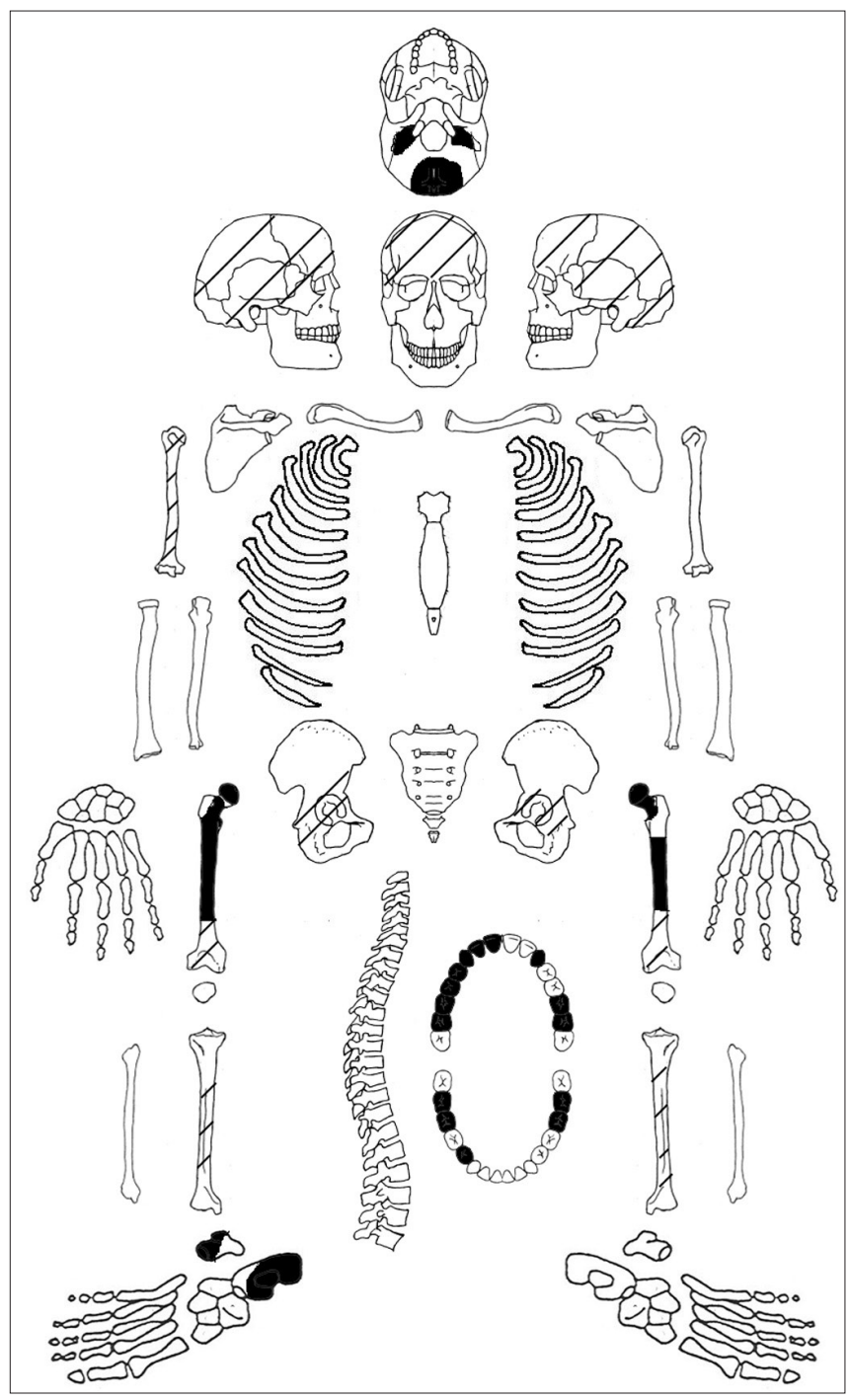

Obr. 6. Nymburk, objekt 358. Schematický nákres zachovalosti a kompletnosti skeletu.

na a stydká kost nebyla zachována vưbec. Stehenní kosti byly na tělech poškozeny, oboustranně byla zachována také osifi- 


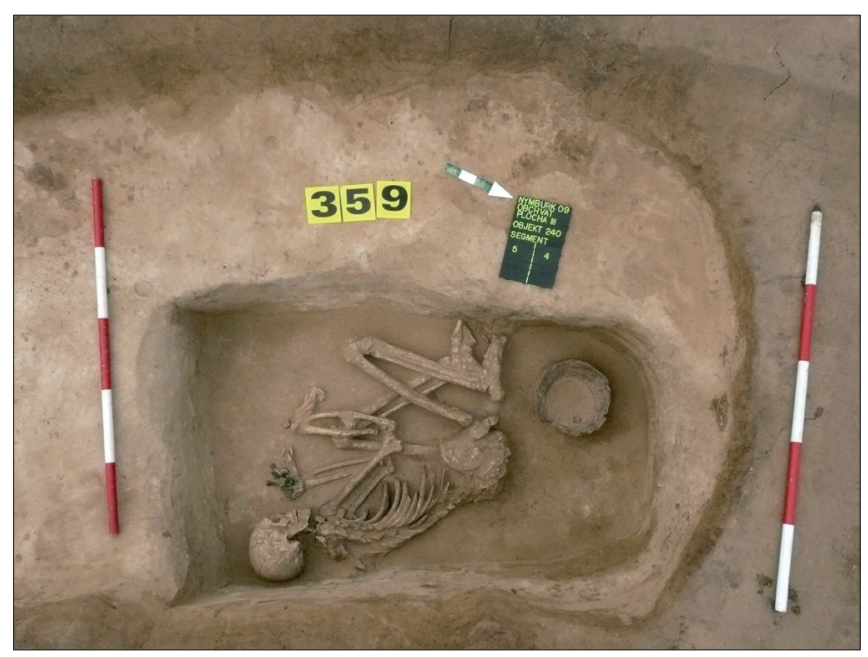

Obr. 7. Nymburk, objekt 359. Celkový pohled na nálezovou situaci.

kační centra hlavice kosti stehenní a distální epifýzy a vlevo i centrum velkého chocholíku. Čéšky byly nalezeny z obou stran. Holenní kosti byly poškozeny na těle, rovněž byla nalezena osifikační centra proximální a distální epifýzy. Pravá lýtková kost byla více poškozena než levá, u obou chyběly proximální a distální konce. $Z$ kostí pravé nohy byla zachována kost patní, hlezenní, lodkovitá, mediální a prostřední kost klínovitá, kost krychlová a druhá až pátá kost nártní. Z levé nohy byly nalezeny kost patní, hlezenní, mediální klínovitá, krychlová a všechny kosti nártní. Rovněž byly nalezeny články prstů z proximální a mediální řady.

Spíše muž (Schutkowski 1993), (dle analýzy DNA pohlaví zatím nepotvrzené, ale $s$ náznakem mužského), dožitý věk 14-16 let (Ubelaker 1978, Stloukal - Hanáková 1978, Schaefer et al. 2009), výška postavy u nedospělého jedince nevypočíávána. Slabý zubní kámen na labiální ploše horních i dolních řezákủ. Povrch všech kostí byl poškozen kořínky rostlin.

\section{Objekt 358 (obr. 5, obr. 6)}

Popis nálezové situace - hloubka $25-30 \mathrm{~cm}$; kostra dospělého jedince ležící na levém boku (SV-JZ), poloha horních končetin neurčitelná, dolní končetiny natažené. Následkem tafonomických procesů ležely dolní končetiny v poloze na zádech. Inventár hrobu zahrnoval keramickou nádobu (kosti bérce obou stran ležely př́mo v nádobě) a drobný bronzový plíšek u nádoby.

Lebka - velmi špatně zachována. Identifikovány pouze fragmenty z týlní kosti a obě kosti skalní. $Z$ dentice byly nalezeny velmi poškozené a rozpadající se zuby $\mathrm{z}$ horní čelisti (vpravo: I1, I2, C, P1, P2, M1, M2; vlevo: C, M1, M2). Zuby z dolní čelisti byly zachovány vpravo: P1, M1, M2; vlevo: M1, M2. Na genetickou analýzu byla dána levostranná dolní druhá stolička. Osový skelet - nezachován.

Horní končetiny - v podstatě nezachované. Nalezeny pouze drobné fragmenty z pravé kosti pažní.

Dolní končetiny - velmi špatně zachované. $Z$ obou pánevních kostí byla zachována pouze malá část $s$ jamkou kyčelního

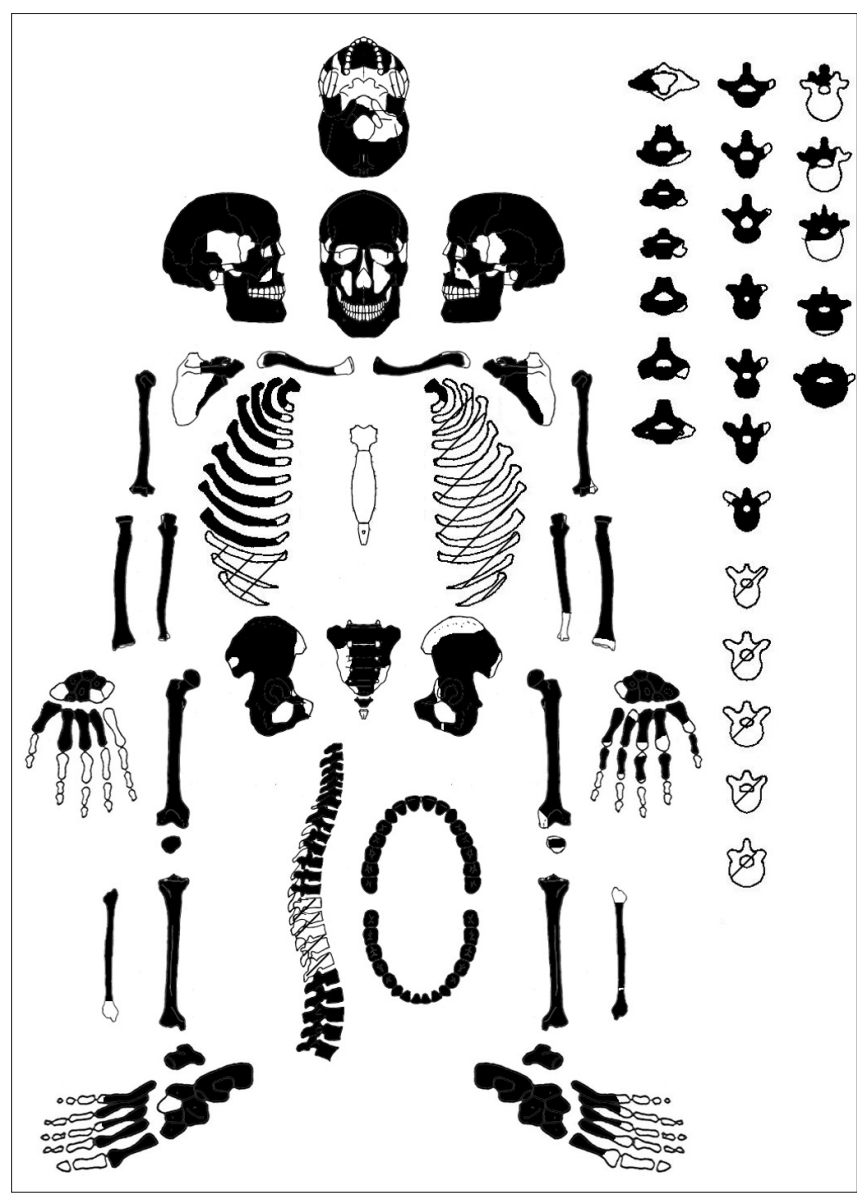

Obr. 8. Nymburk, objekt 359. Schematický nákres zachovalosti a kompletnosti skeletu.

kloubu. Také z obou stehenních kostí byly zachovány pouze poškozené hlavice, část krčků a větši části těl. $Z$ obou kostí holenních byly nalezeny pouze fragmenty těl. Kosti nohy zastupovala poškozená pravostranná kost hlezenní a patní.

Pohlaví antropologicky neurčitelné (dle analýzy DNA žena), dožitý věk 30-50 let (Lovejoy 1985), výška postavy nelze vypočítat.

\section{Objekt 359 (obr. 7, obr. 8)}

Popis nálezové situace - hloubka $75-80 \mathrm{~cm}$; kostra dospělého jedince ležící na levém boku (JV-SZ), velmi skrčená poloha, horní končetiny výrazně pokrčené v loktech (levá dlaň u hlavy), dolní končetiny také výrazně pokrčené $\mathrm{v}$ kolenou (pravá horní končetina ležela na levé dolní končetině). Inventář hrobu zahrnoval keramickou nádobu (u pánve) a v levé dlani drobné zlomky svinutého bronzového drátu a bronzové plišky. Lebka - lehce postmortálně deformována, ale dobře zachována. Spodina lebeční je nekompletní, týlní kost je poškozena vlevo od týlního otvoru, tělo levostranné horní čelisti je výrazně poškozená, chybí velká křídla kosti klínové a $\mathrm{k}$ nim přiléhající části temenních kostí, jařmové oblouky byly odlomeny, chybí nosní kůstky a drobné kůstky obličejové části lebky. Dentice byla kompletně zachována (včetně všech třetích 


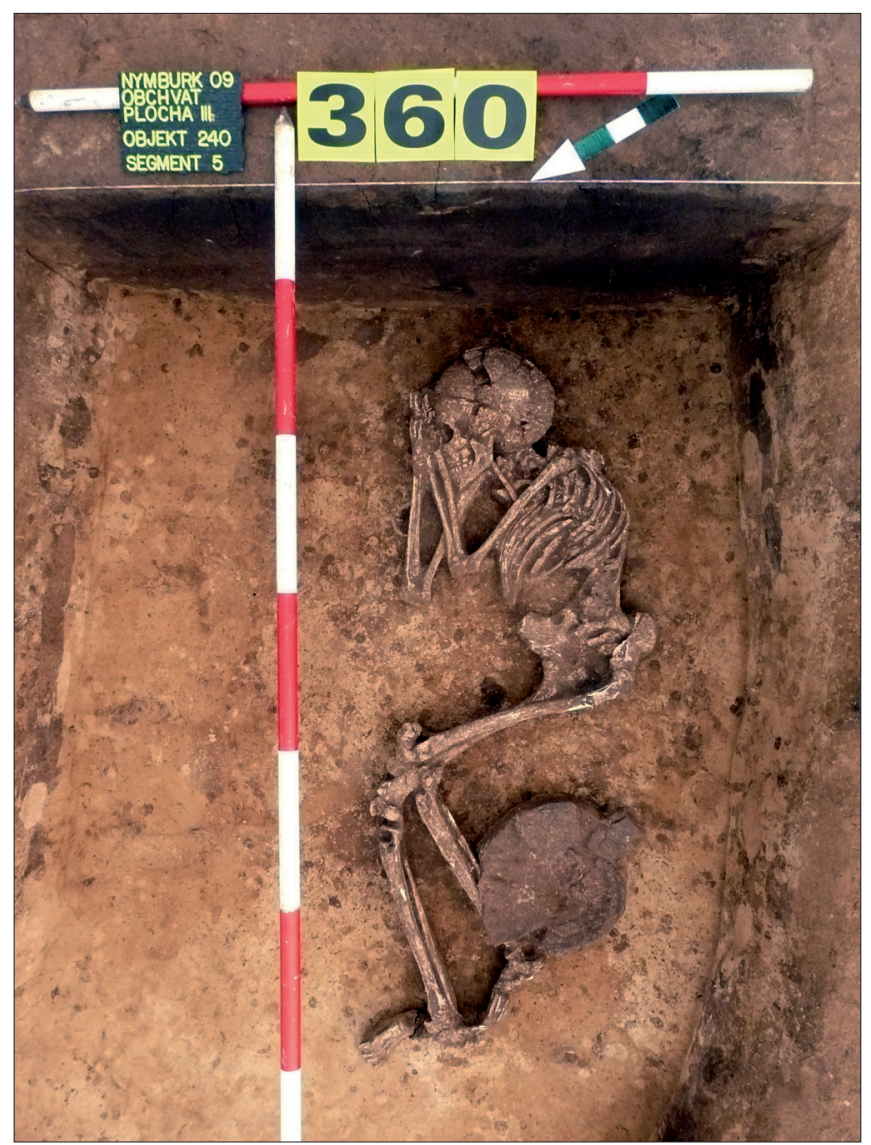

Obr. 9. Nymburk, objekt 360. Celkový pohled na nálezovou situaci.

stoliček). Na genetickou analýzu byla dána levostranná horní třetí stolička.

Osový skelet - dobře zachovaný. Nosič nemá levou polovinu, jinak byly krční obratle kompletní a jen lehce poškozené. Z identifikovaných sedmi horních hrudních obratlů nesly 4 na dolní terminální ploše obratlového těla výrazné Schmorlovy uzly (Th4 - Th7). Jedná se o projev deformační spondylózy (spondylosis deformans), která je považována za páteřní lokalizaci deformační artrózy. Schmorlovy uzly jsou okrouhlé nebo lineární deprese na terminálních plochách obratlových těl s průměrem do $0,5 \mathrm{~cm}$ a hloubkou do $1-1,5 \mathrm{~cm}$. Tyto útvary jsou způsobené výhřezem pulpózního jádra meziobratlové destičky vertikálním směrem proti obratlovému tělu (Horáčková - Strouhal - Vargová 2004, 57). Zbylé hrudní obratle byly fragmentarizovány. Bederní obratle byly kompletní, ale první tř̌i byly velmi poškozeny. Křížová kost byla dobře zachována, pouze vpravo poškozena. $Z$ anatomických variet je zajímavý nález sakralizovaného prvního kostrčního obratle. První žebro bylo zachováno oboustranně, pouze sternální konec byl poškozený. Žebra z pravé strany měla pouze poškozen sternální konec - identifikováno bylo 1. až 9. žebro, zbylá žebra byla fragmentarizována. Levostranná žebra se dochovala v neidentifikovatelných fragmentech.

Horní končetiny - dobře zachovány. Pravostranné klíční kosti chyběla mediální část a laterální byla lehce poškozena, levostranná měla pouze poškozený laterální konec. Na levé klíční

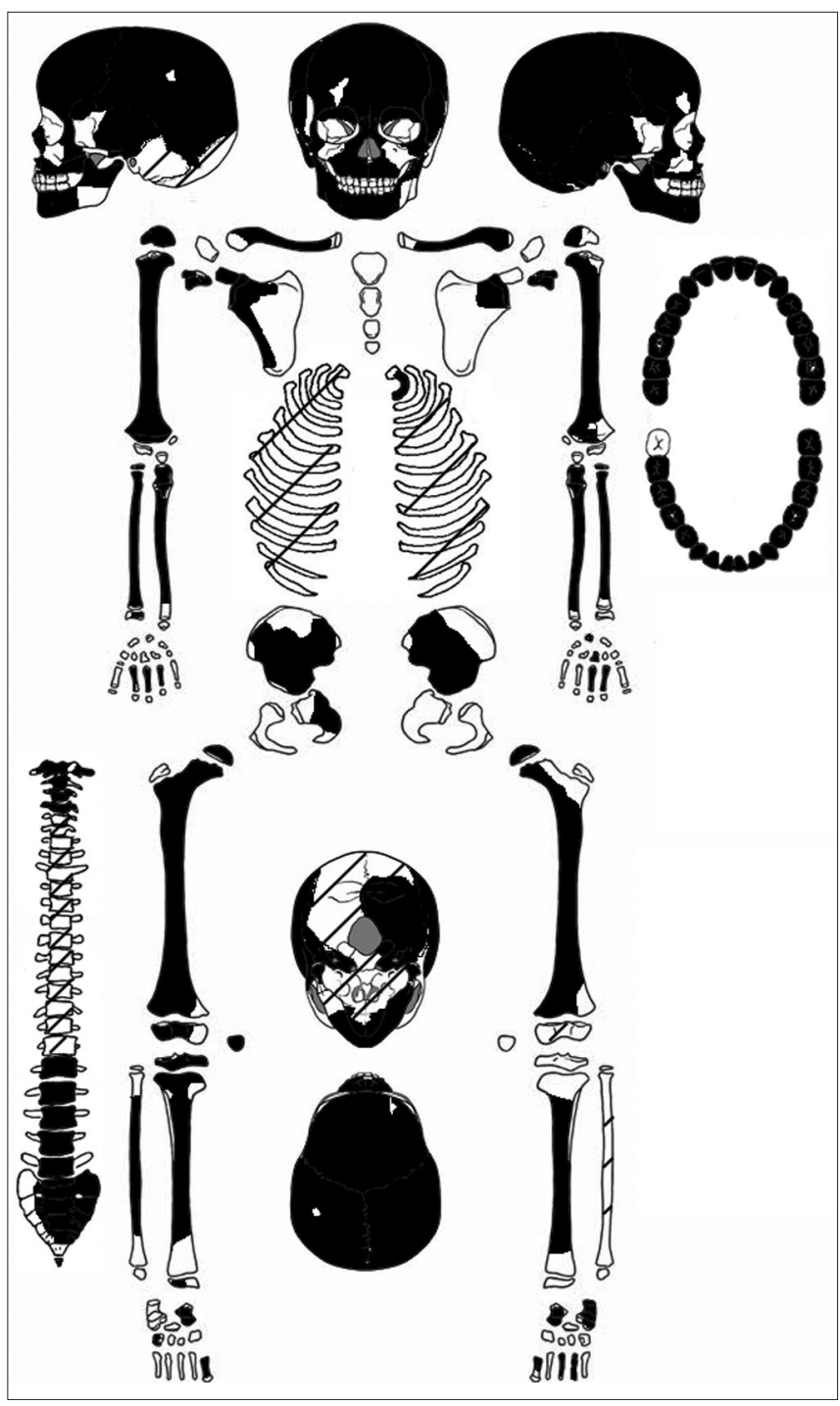

Obr. 10. Nymburk, objekt 360. Schematický nákres zachovalosti a kompletnosti skeletu.

kosti byla nalezena anatomická varieta fossa costoclavicularis (impressio ligamenti costoclavicularis), která souvisí s nadměrným zatížením žebroklíčního vazu (Stloukal et al. 1999, 147). Obě lopatky měly chybějící mediální polovinu. Pažní kosti byly oboustranně kompletní, vřetenní a loketní kosti byly vpravo nepoškozené a vlevo jim chyběl distální konec. Z kostí pravé ruky byly nalezeny kost lodkkovitá, poloměsíčitá, trojhranná, kost mnohohranná menší, kost hlavatá a 1. až 4 . kost záprstní. Kosti levé dlaně zastupovaly všechny kosti zápěstní (kromě kosti hráškové), všechny kosti záprstní a všechny prstní články proximální řady a tř̀i články mediální řady. Kosti zápěstní a záprstní byly zabarvené oxidy kovů.

Dolní končetiny - dobře zachovány. Pravá pánevní kost je na okrajích poškozená, levé chybí horní část lopaty kyčelní. Stehenní kosti byly jen drobně poškozené, pravá čéška je nepoškozená, levá má poškozenou horní a dolní část. Pravostranná holenní kost je nepoškozená, levostranná je poškozená v distální části těla. Lýtkové kosti pravé strany chybí distální konec a kosti levé strany chybí proximální konec. Z kostí pravé 
nohy byly zachovány všechny kosti zánártní (kromě laterální klínové kosti) a všechny kosti nártní. Vlevo byly zachovány kompletně všechny kosti zánártní i nártní.

Muž (Acsádi - Nemeskéri 1970, Černý - Komenda 1980, Novotný et al. 1993), (analýza DNA se prozatím nezdařila), dožitý věk 30-40 let (Lovejoy 1985), výška postavy 178,4 \pm $4,89 \mathrm{~cm}$ (dle pravostranné pažní kosti, Sjøvold 1990); 183,5 $\pm 4,49 \mathrm{~cm}$ (dle pravostranné stehenní kosti, Sjøvold 1990). Slabý zubní kámen na labiální ploše horních i dolních řezákủ, Schmorlovy uzly na Th4-Th7. Sakralizace prvního kostrčního obratle, fossa costoclavicularis (impressio ligamenti costoclavicularis. Povrch všech kostí byl poškozen kořínky rostlin.

\section{Objekt 360 (obr. 9, obr. 10)}

Popis nálezové situace - hloubka $40-50 \mathrm{~cm}$; kostra nedospělého jedince ležící na pravém boku (JV-SZ), horní končetiny výrazně pokrčené $\mathrm{v}$ loktech (část předloktí a dlaně přímo u lebky), dolní končetiny pokrčené v kolenou. Inventár hrobu zahrnoval keramickou nádobu (u levého bérce).

Lebka - dobře zachovaná (obr. 11). Levá polovina kosti týlní je fragmentarizována, spodina lebeční je nekompletní, dolní čelist chybí levý angulus mandibulae. Obě horní čelisti byly poškozeny na těle a oboustranně chybí velká křídla kosti klínové. Trvalá dentice byla kompletní, pouze žádná třetí stolička nebyla ještě prořezána (vpravo dole nebyla $\mathrm{v}$ čelisti ani viditelná). Na genetickou analýzu byl dán pravostranný horní první třenový zub.

Osový skelet - dobře zachovaný. Byly identifikovány $\mathrm{C} 1$ až C4, zbylé krční obratle a hrudní obratle byly fragmentarizovány, bederní obratle byly slabě poškozeny a $\mathrm{v}$ plném počtu. Kř́žové obratle byly na pravé straně poškozeny a byly zachovány pouze S1 až S4. Žebra byla zachována ve fragmentech.

Horní končetiny - dobře zachované. Obě klíční kosti byly zachovány téměr celé (oba konce chyběly). Dále byl nalezen z pravé lopatky zlomek hřebene, nepřirostlý výběžek zobcovitý a část laterálního okraje. $\mathrm{Z}$ pravé strany byla zachována kloubní jamka a nepřirostlý výběžek zobcovitý. Pažní kosti byly zachovány, až na drobná poškození konců, celé (levá byla více poškozena). Nepřirostlá hlavice pažní kosti byla rovněž nalezena na obou stranách (levá je poškozena). Pravostranné i levostranné kosti loketní a vřetenní chyběl distální konec těla. $U$ obou vřetenních kostí byly nalezeny i nepřirostlé proximální epifýzy a u pravé i poškozená nepřirostlá distální epifýza. Z kostí pravé ruky se dochovala pouze pravostranná druhá až čtvrtá kost záprstní. $Z$ levé strany byly zachovány kost poloměsíčitá, hlavatá a druhá a třetí kost záprstní.

Dolní končetiny - středně dobře zachované. Oběma kostem kyčelním chyběla horní polovina kosti, kost sedací byla zachována jen z pravé strany a je poškozena a stydká kost nebyla zachována vůbec. Stehenní kosti byly na těle poškozeny (levá výrazně poškozena i na krčku), oboustranně byla zachována také osifikační centra hlavice stehenní kosti a distální epifýzy (levé pouze ve fragmentech). Čéška byla nalezena pouze pravá. Holenním kostem chyběly distální konce a levé i proxi-

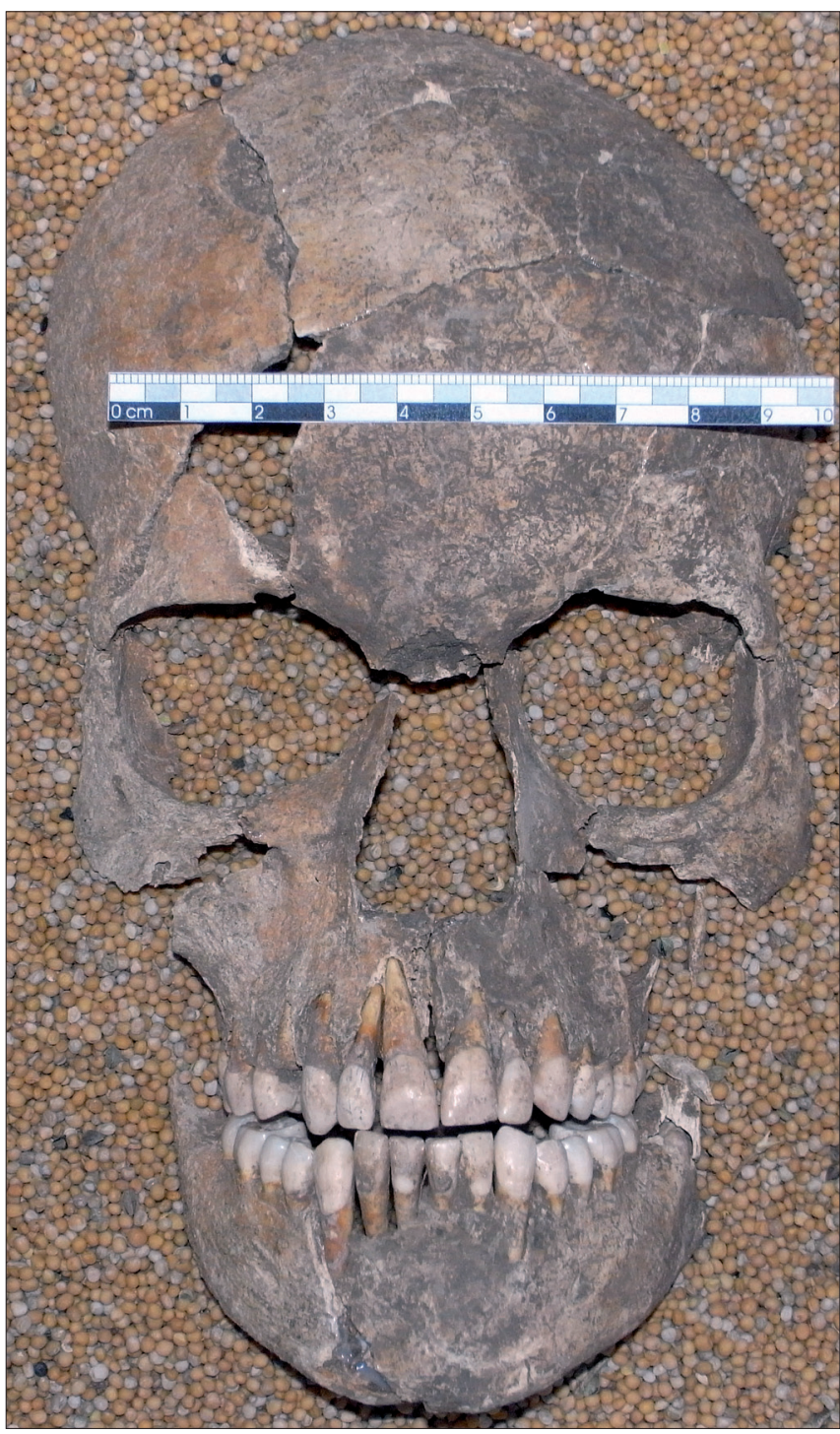

Obr. 11. Nymburk, objekt 360. Lebka (pohled v norma frontalis).

mální konec. Rovněž byla nalezena na pravé straně osifikační centra proximální a distální epifýzy (poškozené). Pravé lýtkové kosti chyběly oba konce a levá byla zachována fragmentárně. Z kostí pravé nohy byla zachována kost hlezenní, kost krychlová a první kost nártní. $Z$ levé nohy byly nalezeny kost patní, hlezenní a první, třetí a čtvrtá kost nártní.

Spíše žena (Schutkowski 1993), (dle analýzy DNA žena), dožitý věk 12-14 let (Ubelaker 1978, Stloukal - Hanáková 1978, Schaefer et al. 2009), výška postavy u nedospělého jedince nevypočítávána. Střední zubní kámen na labiální ploše dolních řezáků. Povrch všech kostí byl poškozen kořínky rostlin.

\section{Objekt 377 (obr. 12)}

Popis nálezové situace - hloubka $40-50 \mathrm{~cm}$; kostra dospělého jedince ležící pravděpodobně na pravém boku (pravděpodobně $\mathrm{V}-\mathrm{Z}$ ). Inventář hrobu zahrnoval $13 \mathrm{~cm}$ dlouhou bronzovou jehlici u hlavy. 


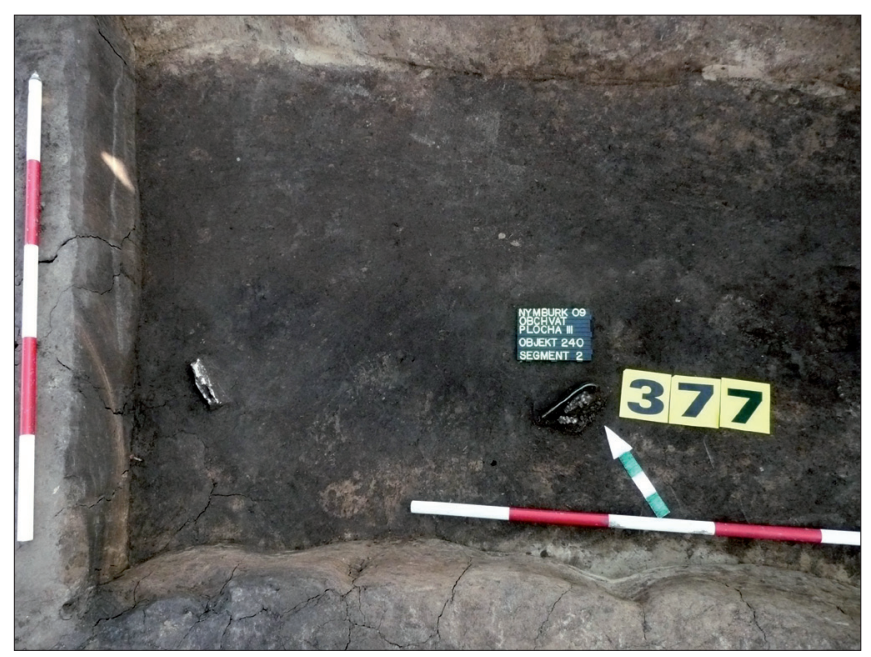

Obr. 12. Nymburk, objekt 377. Celkový pohled na nálezovou situaci.

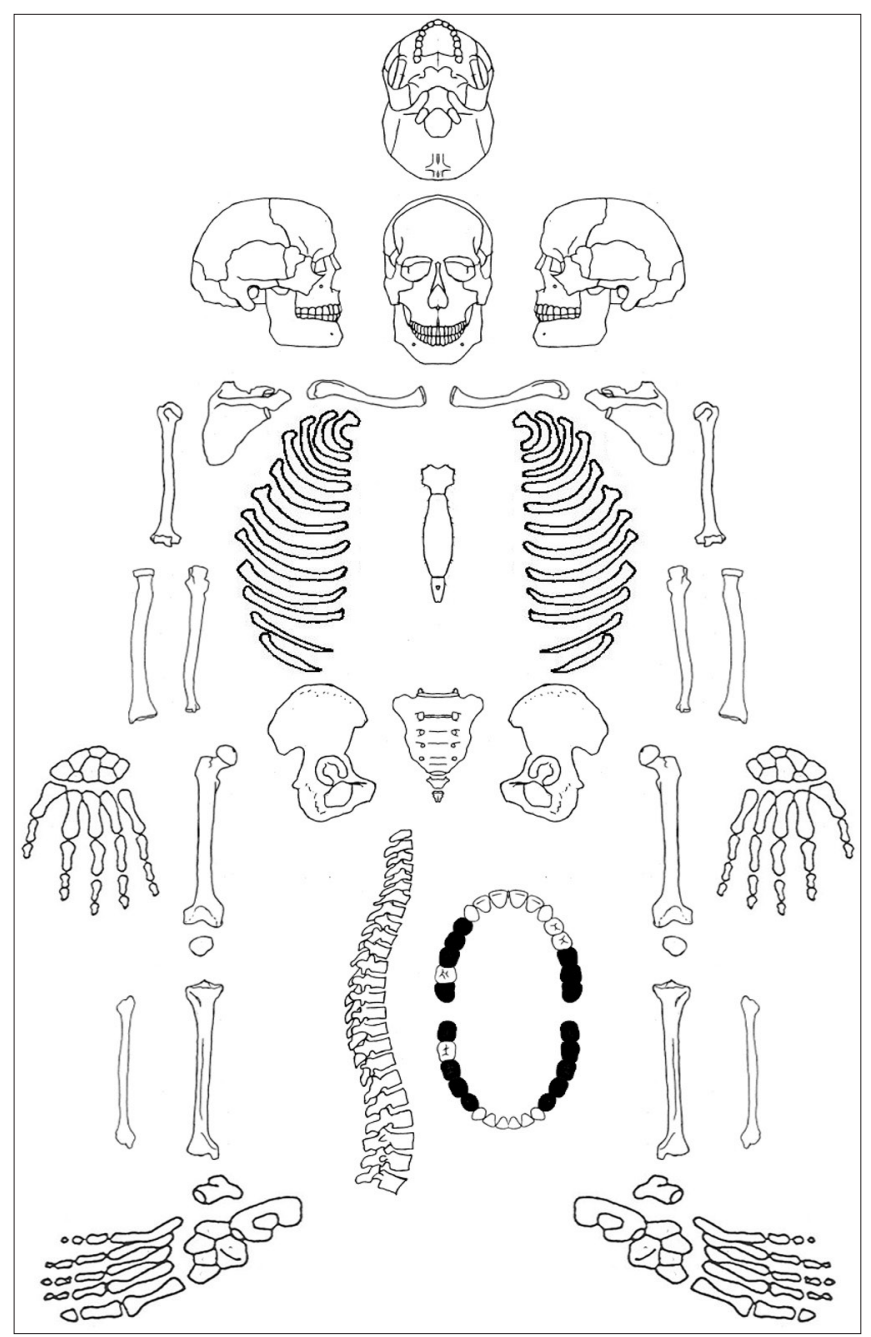

Obr. 13. Nymburk, objekt 377. Schematický nákres zachovalosti a kompletnosti skeletu.

Lebka - nezachována. Nalezeny pouze poškozené zuby částečně v anatomickém pořadí (obr. 13). Identifikované zuby horní čelisti (vpravo: P1, P2, M1, M3; vlevo: M1, M2, M3) a dolní čelisti (vpravo: P1, P2, M1, M3; vlevo: P1, P2, M1, M2,

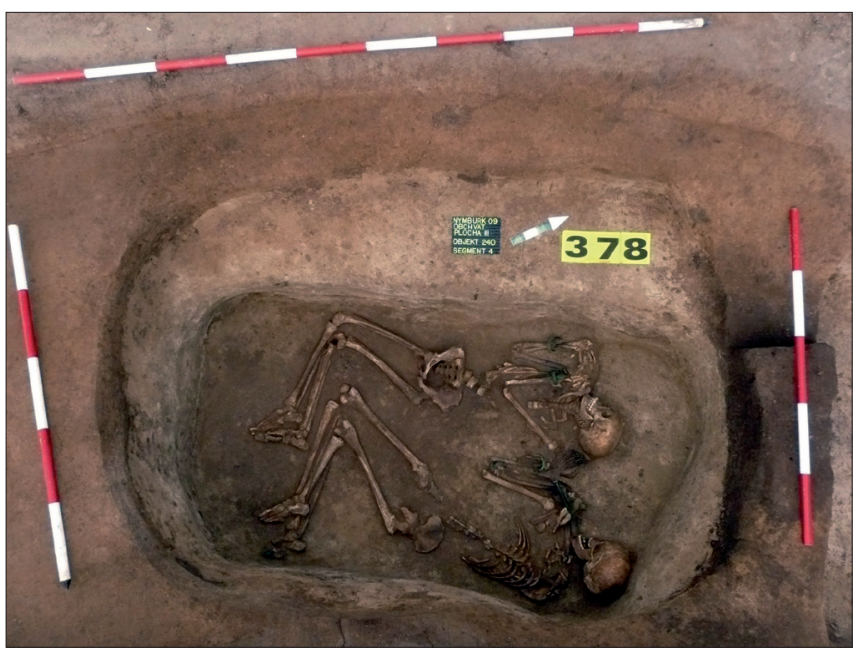

Obr. 14. Nymburk, objekt 378. Celkový pohled na nálezovou situaci.

M3). Na genetickou analýzu byla dána pravostranná dolní třetí stolička.

Osový skelet - nezachován.

Horní končetiny - nezachovány.

Dolní končetiny - zachován neidentifikovatelný fragment dlouhé kosti.

Pohlaví antropologicky neurčitelné (dle analýzy DNA pohlaví zatím nepotvrzené, ale s náznakem mužského), dožitý věk 35-40 let (Lovejoy 1985), výška postavy nelze vypočítat.

\section{Objekt 378/1 (obr. 14, obr. 15)}

Popis nálezové situace - hloubka $75-80 \mathrm{~cm}$; kostra (kostra 1, ležící v SZ polovině hrobu) nedospělého jedince ležící na pravém boku (SV-JZ), horní končetiny výrazně pokrčené v loktech (levá dlaň téměř u lebky), dolní končetiny pokrčené v kolenou. Následkem tafonomických procesů ležel trup a pánev na zádech. Inventár hrobu zahrnoval bronzové náramky na obou předloktích.

Lebka - postmortálně deformována, dobře zachována (obr. 16). Obličejová část lebky byla zachována velmi dobře (pouze jařmové oblouky byly odlomené). Pravá část mozkovny chybí, spodina lebeční je také nekompletní (pravá polovina týlní kosti chybí). Dolní čelisti chybí pravá část těla (od M1) a pravé rameno. Dentice zachována kompletní. V horní čelisti byly vidět neprořezané třetí stoličky, $v$ dolní čelisti vidět nebyly. Na genetickou analýzu byla dána pravostranná dolní první stolička.

Osový skelet - středně špatně zachovaný. Krční obratle byly zachovány všechny a míra poškození stoupá směrem dolů. Hrudní obratle byly zachovány pouze jako těla a bylo jich nalezeno prvních osm. $\mathrm{Z}$ bederních obratlů byly nalezeny tř̌i spodní. Kř́žová kost měla odlomenou spodní část na levé straně. Žebra byla z pravé strany zachována ve zlomcích, první žebro bylo méně poškozeno. Z levé strany se dochovala jen první dvě žebra.

Horní končetiny - dobře zachovány. Pravostranné klíční kosti chyběla mediální část a laterální byla lehce poškozena, le- 


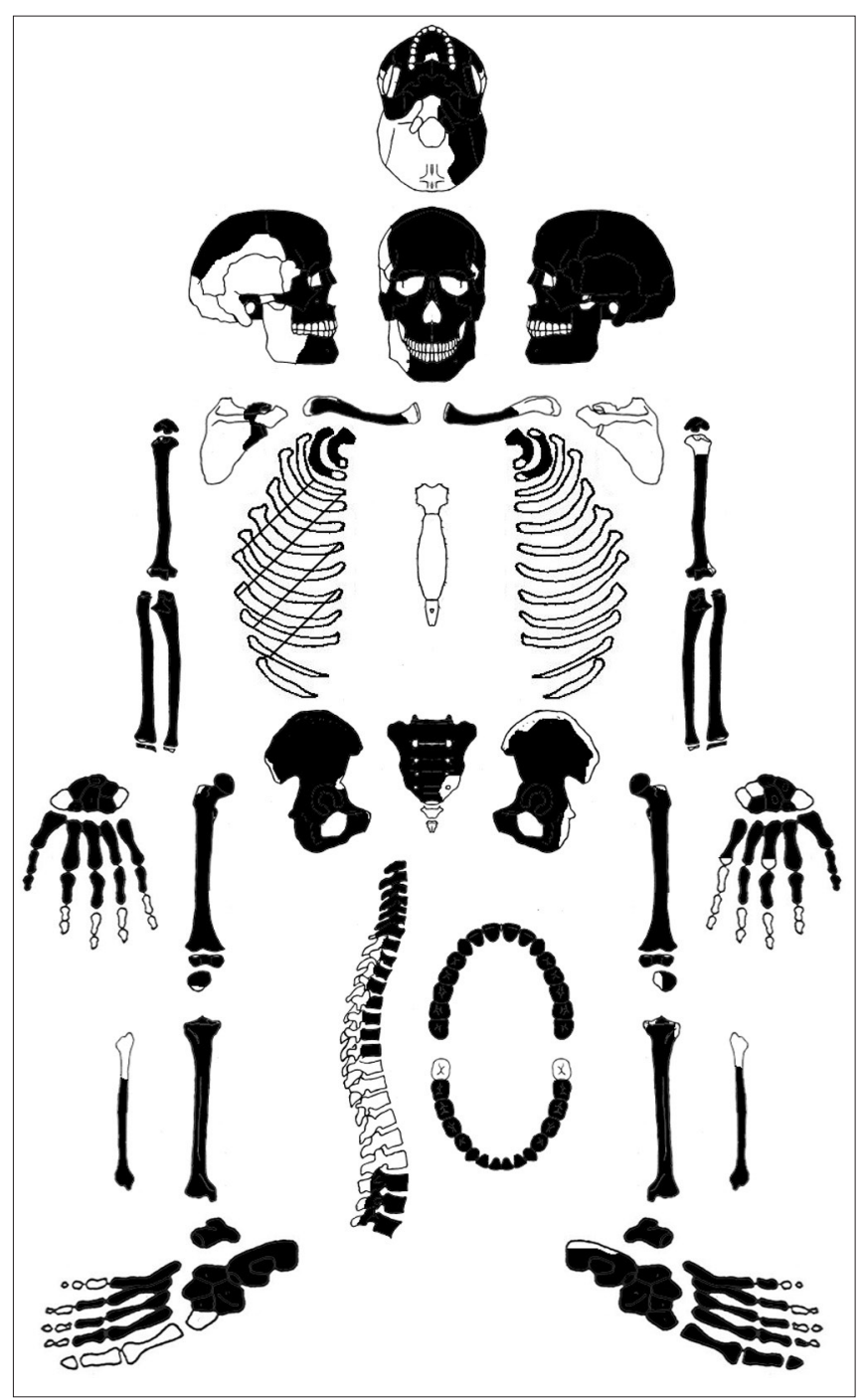

Obr. 15. Nymburk, objekt 378/1. Schematický nákres zachovalosti a kompletnosti skeletu.

vostranné chyběla laterální třetina kosti. Pravá lopatka měla zachovánu jen část přiléhající ke kloubní jamce, zobcovitý výběžek a část laterálního okraje. Levostranná lopatka se nedochovala. Pažní kosti byly oboustranně kompletní (levé chyběla horní část těla), nepřirostlá hlavice kosti pažní byla rovněž nalezena na obou stranách. Vřetenní a loketní kosti byly na obou stranách nepoškozené (u vřetenních kostí byly zachovány i nepřirostlé distální epifýzy) a byly v místě náramků zabarvené oxidy kovů. Z kostí pravé ruky byly nalezeny kost lodkkovitá, poloměsíčitá, trojhranná, kost mnohohranná menší, kost hlavatá a hákovitá, všechny kosti záprstní a všechny prstní články z proximální řady (u palce navíc i článek distální). Z levé strany byly zachovány kost lod'kovitá, poloměsíčitá, kost mnohohranná menší, kost hlavatá a kost hákovitá, všechny kosti záprstní a druhý až čtvrtý prstní článek z proximální řady a u palce i distální prstní článek. Zápěstní kosti a proximální konce kostí záprstních byly lehce zabarveny oxidy kovů. Byly nalezeny rovněž neidentifikovatelné prstní články z mediální řady.

Dolní končetiny - dobře zachovány. Pravá pánevní kost je

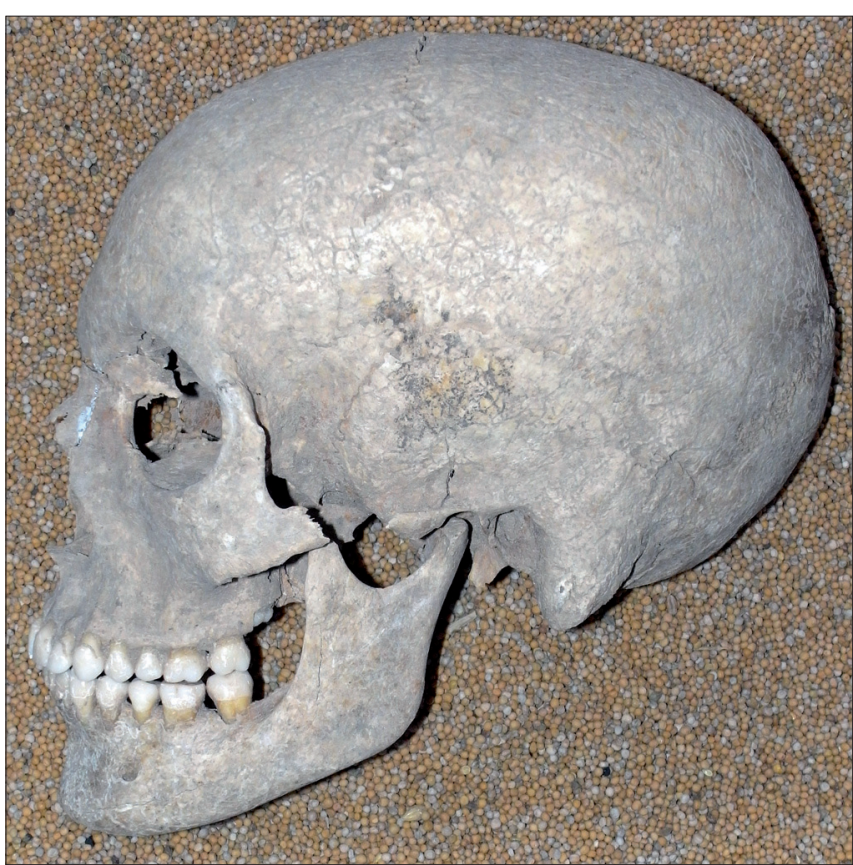

Obr. 16. Nymburk, objekt 378/1. Lebka (pohled v norma lateralis sinistra).

téměř nepoškozená, levé chybí horní okraj lopaty kyčelní a sedací hrbol je také lehce poškozen. Stehenní kosti byly jen drobně poškozené (byly oboustranně nalezeny nepřirostlé distální epifýzy), pravá čéška je lehce poškozená, levá čéška nemá mediální polovinu. Pravostranná holenní kost je nepoškozená, levostranná je poškozená na proximálním konci. Oběma lýtkovým kostem chybí proximální konec. Z kostí pravé nohy byly zachovány všechny kosti zánártní (kromě mediální klínové kosti), všechny kosti nártní (kromě palcové) a 2. až 4. prstní článek z proximální řady. Vlevo byly zachovány kompletně všechny kosti zánártní i nártní a celá proximální řada prstních článků (u palce i distální prstní článek). Spíše muž (Schutkowski 1993), (dle analýzy DNA muž), dožitý věk 16-18 let (Ubelaker 1978, Stloukal - Hanáková 1978, Schaefer et al. 2009). Střední zubní kámen na labiální ploše horních i dolních řezáků. Povrch všech kostí byl poškozen kořínky rostlin.

\section{Objekt 378/2 (obr. 14, obr. 17)}

Popis nálezové situace - hloubka 75-80 cm; kostra (kostra 2, ležící v JV polovině hrobu) dospívajícího (stupeň osifikace chrupavčitého spojení mezi bazální částí kosti týlní a tělem kosti klínové nebylo možné kvůli poškození hodnotit) jedince ležící na pravém boku (SV-JZ), horní končetiny výrazně pokrčené v loktech, dolní končetiny pokrčené v kolenou. Následkem tafonomických procesů ležel trup a pánev na břiše a pravá pažní kost byla pod hrudníkem umístěna rovnoběžně s klíčními kostmi, a díky tomu se pravý loket tedy nacházel u levého ramene a pravé zápěstí u levého lokte. Inventář hrobu zahrnoval bronzové náramky na obou předloktích, dva bronzové prsteny na levé ruce (3. a 4. prst) a jeden prsten druhotně přemístěný (pravděpodobně hlodavci) k levému rameni. Dále 


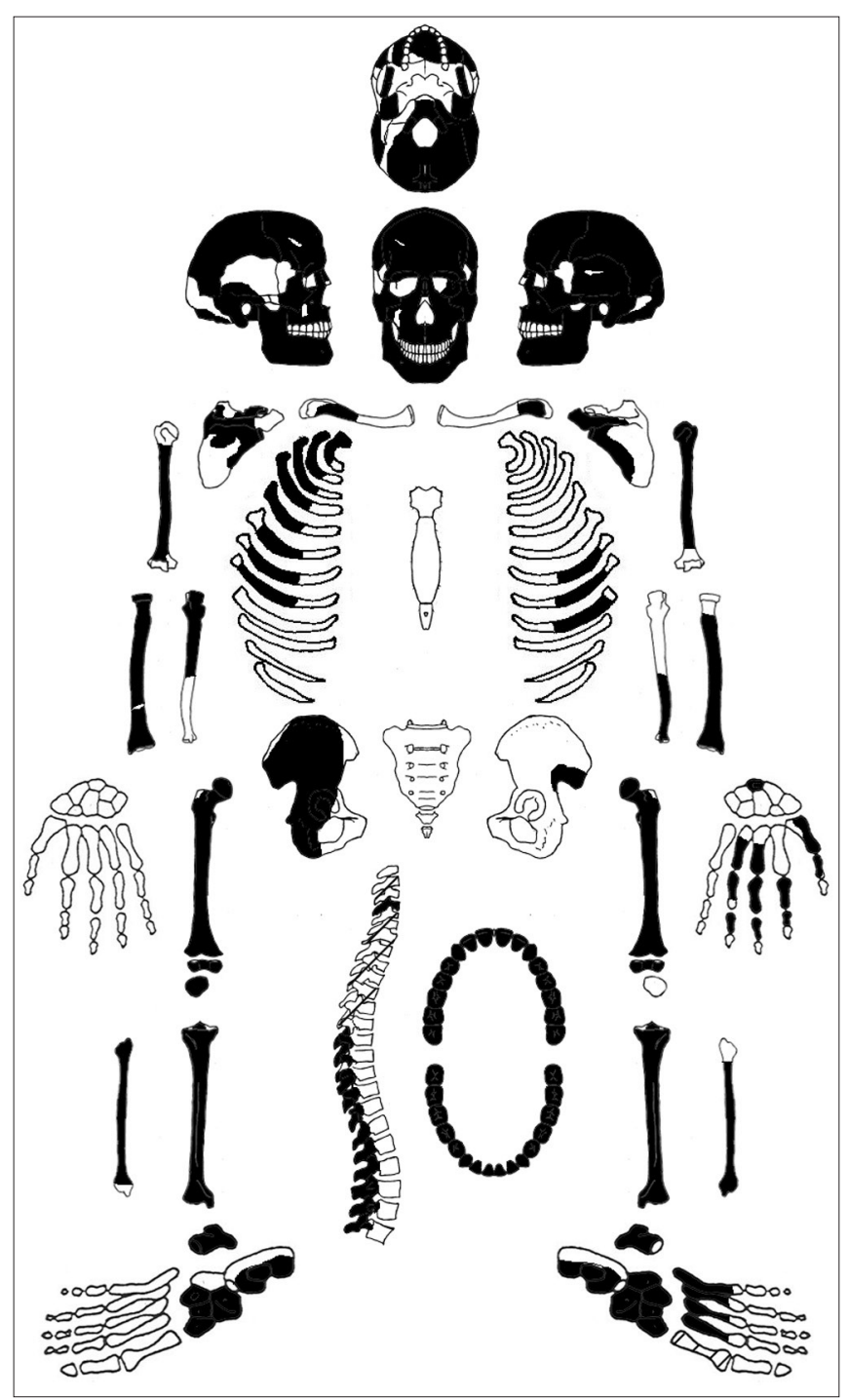

Obr. 17. Nymburk, objekt 378/2. Schematický nákres zachovalosti a kompletnosti skeletu.

byla nalezena $32 \mathrm{~cm}$ dlouhá bronzová jehlice s pečetítkovitou hlavicí (u levého ramene), dvě drobné bronzové vlasové ozdoby (spirálky) a $4 \mathrm{~mm}$ široký a $2 \mathrm{~mm}$ vysoký plochý jantarový korálek (u pravého ramene). U pravého chodidla byl nalezen další bronzový prsten.

Lebka - dobře zachována (obr. 18). Spodina lebeční, až na tvrdé patro, týlní kost a obě skalní kosti, nebyla zachována. Obličejová část lebky byla velmi dobře zachována, pouze pravostranná horní čelist byla poškozena a pravá očnice byla více nekompletní. Zbylá část lebky byla více nekompletní na pravé straně (chyběla větší část šupiny kosti spánkové). Také bylo zachováno pravostranné kladívko. Dolní čelist byla posmortálně deformovaná (rozlomena uprostřed) a na pravé polovině zabarvena oxidy kovů a výrazněji poškozená. Dentice byla zachovaná kompletní ( $\mathrm{M} 3$ byla plně prořezána pouze vlevo dole). Na genetickou analýzu byla dána pravostranná horní druhá stolička.

Osový skelet - středně špatně zachovaný. Krční obratle byly zachovány pouze $\mathrm{C} 4$ až C6, byly fragmentarizovány a zabar-

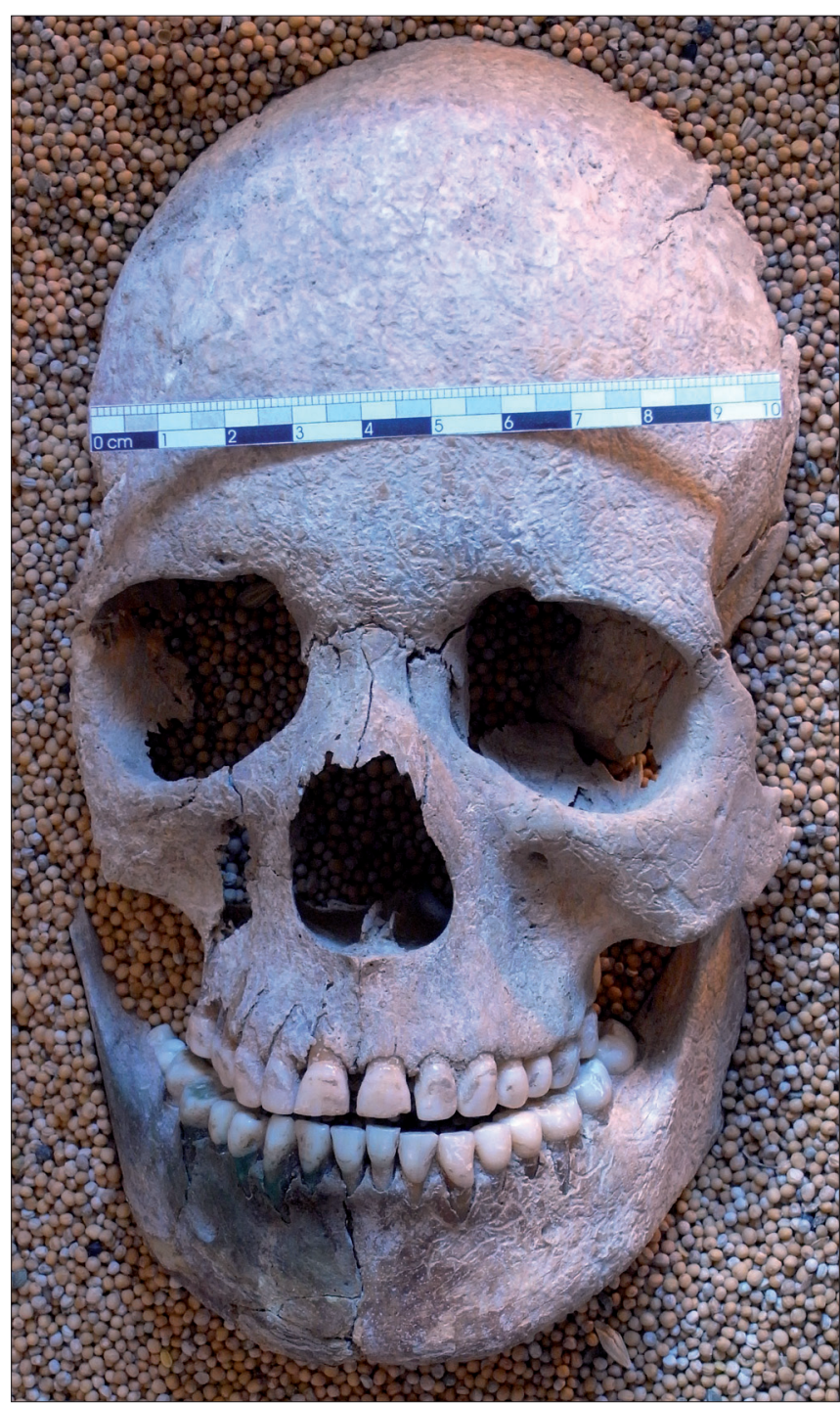

Obr. 18. Nymburk, objekt 378/2. Lebka (pohled v norma frontalis).

veny oxidy kovů. Všechny hrudní obratle byly fragmentarizovány a těla nebyla zachována. Bederní obratle byly zachovány také bez obratlových těl. Kř́ížová kost se vůbec nedochovala. Pravostranná žebra byla lépe zachována než levostranná a bylo jich nalezeno prvních osm. $Z$ levé strany byly zachovány pouze středové části tř́i dolních žeber.

Horní končetiny - dobře zachovány. Pravá klíční kost byla zachována pouze jako fragment laterální části těla (zabarvený oxidy kovů), z levostranné klíční kosti byl zachován pouze laterální konec a byl zabarven oxidy kovi̊. Pravá lopatka byla zastoupena částí přiléhající ke kloubní jamce, zobcovitým výběžkem, celou spina scapulae a částí laterálního okraje. Levá lopatka byla poškozena a byla zachována pouze část přiléhající ke kloubní jamce, část hřebene a část laterálního okraje. Pravostranná kost pažní neměla proximální konec, distální byl výrazněji poškozený a v distální části těla byla kost zabarvena oxidy kovů. Pravá kost vřetenní byla poškozena, v distální části byla kost zabarvena oxidy kovů, ale byla zachována i nepřirostlá distální epifýza. Pravé kosti loketní chyběla distální 


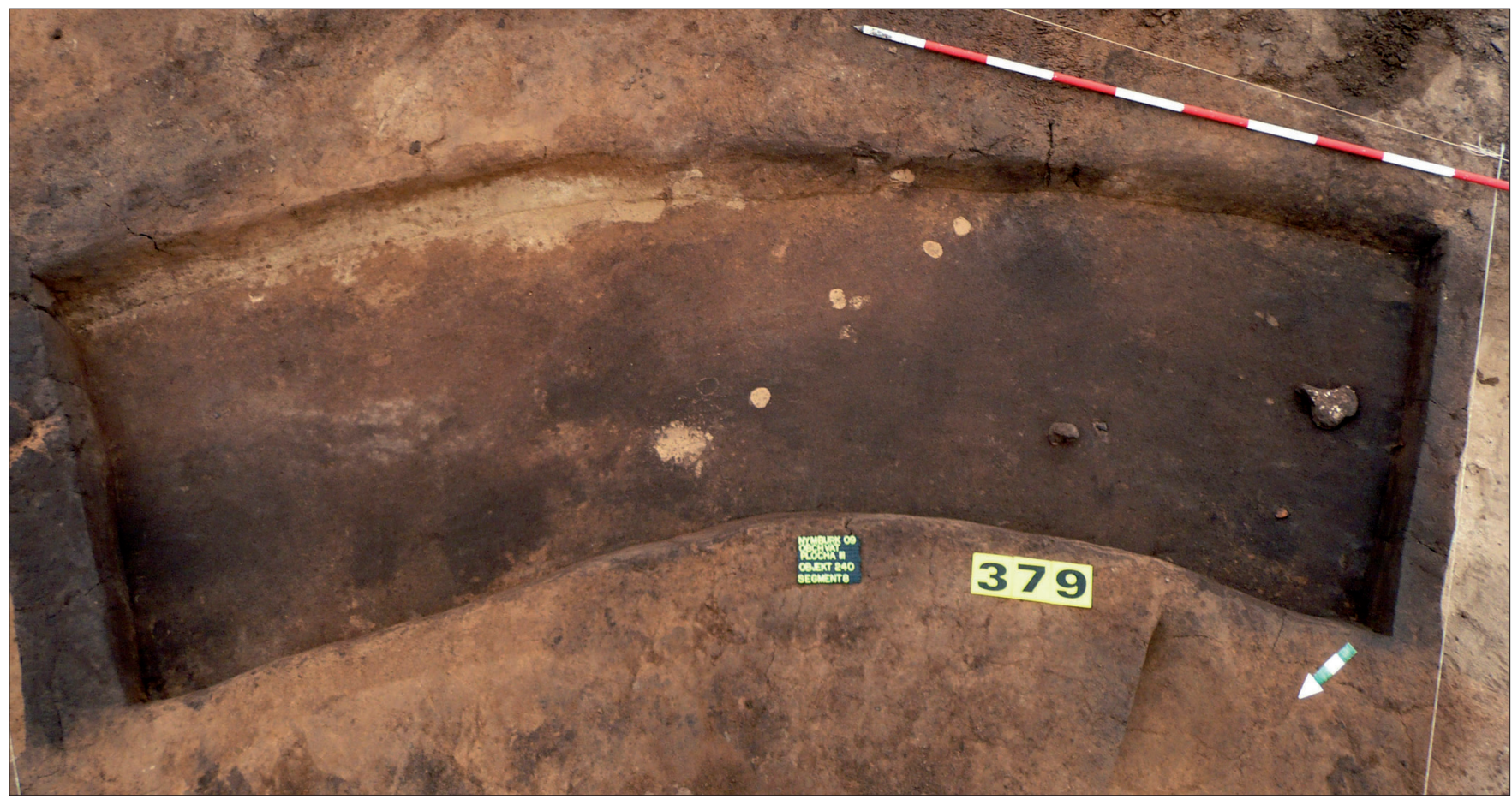

Obr. 19. Nymburk, objekt 379. Celkový pohled na nálezovou situaci.

polovina kosti. Levostranná pažní kost neměla zachován distální konec a byla lehce zabarvena oxidy kovů v distální části těla. Levá kost vřetenní byla fragmentarizována a chyběla jí proximální část. Loketní kosti levé strany chyběla proximální polovina kosti. Obě kosti byly v distální části zabarveny oxidy kovů. Kosti ruky byly zachovány pouze z levé strany: kost poloměsíčitá a 1., 3. a 4. kost záprstní (všechny poškozené v proximální ćásti) a k těmto prstům byly zachovány i prstní články proximální a k 3. a 4. prstu i mediální řady. Dále byl zachován prstní článek proximální a mediální řady ukazováčku. Kosti ruky byly zabarveny oxidy kovů.

Dolní končetiny - dobře zachovány. Pravá pánevní kost byla lépe zachována než levá, chybí jí stydká část a na okrajích je kost poškozena. Z levé pánevní kosti byl zachován pouze fragment s částí jamky kyčelního kloubu. Pravostranná kost stehenní (distální epifýza nepřirostlá), holenní i lýtková byly bez výraznějších poškození (lýtkové chybí distální konec). Pravá čéška byla nepoškozená. Levá kost stehenní (distální epifýza nepřirostlá), holenní a lýtková byly rovněž pouze lehce poškozeny (lýtkové chybí proximální konec). Kosti chodidel byly poškozeny. Vpravo byly zachovány všechny kosti zánártní kromě kosti krychlové a vlevo nechyběla žádná kost. Vlevo byly zachovány i všechny kosti nártní, ale palcová pouze fragmentárně.

Žena (Acsádi - Nemeskéri 1970, Černý - Komenda 1980, Novotný et al. 1993), (analýza DNA se prozatím nezdařila), dožitý věk 17-20 let (Lovejoy 1985, Ubelaker 1978, Schaefer et al. 2009), výška postavy 170,5 $\pm 4,49 \mathrm{~cm}$ (dle pravostranné stehenní kosti, Sjøvold 1990). Střední zubní kámen na labiální ploše horních i dolních řezáků. Povrch všech kostí byl poškozen kořínky rostlin.
Objekt 379 (obr. 19)

Lidské kosti nenalezeny. Nalezena pouze zvířecí kost z většího zvířete (zlomek pánevní kosti).

\section{ZÁVĚR}

Předběžné výsledky analýzy nalezeného souboru (tab. 1) ukázaly ženské pohlaví u 3 jedinců, mužské u 2 a nejisté (spíše mužské) u 2 pohřbených jedinců. Dožitý věk se podařilo určit u všech 7 jedinců, a pokrýval rozmezí 12 až 50 let (12-14, 14-16, 16-18, 17-20, 30-40, 35-40, 30-50 let). Vzhledem $\mathrm{k}$ tomu, že 3 jedinci byli nedospělí (výška postavy u nich proto nebyla určována), a další 2 dospělí jedinci byli zachováni tak, že výpočet výšky postavy nebylo možné provést, byla výška postavy vypočítána úspěšně pouze u jednoho dospělého muže (velmi vysoká výška postavy) a u jedné dospívající ženy (velmi vysoká výška postavy). Metrické hodnocení zkoumaného souboru je shrnuto v tabulkách (tab. 2; tab. 3). Při antropologickém zpracování byl kladen důraz na sledování anatomických variet, jejichž výskyt by mohl potvrdit př́ibuznost pohřbených jedinců. Bohužel z tohoto hlediska se příbuznost nepotvrdila. Z těchto variet je zajímavý nález sakralizovaného prvního kostrčního obratle u dospělého muže (objekt 359), dále byla na levé klíční kosti téhož jedince nalezena fossa costoclavicularis (impressio ligamenti costoclavicularis), která souvisí s nadměrným zatížením žebroklíčního vazu. Ve sledovaném materiálu nebyly zachyceny žádné výrazné patologické změny. Vyskytoval se pouze slabý a střední 


\begin{tabular}{|l|c|c|c|c|}
\hline \multirow{2}{*}{ Objekt } & \multicolumn{2}{|c|}{ Pohlaví } & \multirow{2}{*}{ Věk } & \multirow{2}{*}{ Výška postavy } \\
\cline { 2 - 3 } & antropologické & genetické & & - \\
\hline 323 & spíše muž & spíše muž & $14-16$ & - \\
\hline 358 & neurčitelné & žena & $30-50$ & $183,5 \pm 4,49 \mathrm{~cm}$ \\
\hline 359 & muž & - & $30-40$ & - \\
\hline 360 & spíše žena & žena & $12-14$ & - \\
\hline 377 & neurčitelné & spíše muž & $35-40$ & - \\
\hline $378 / 1$ & spíše muž & muž & $16-18$ & $170,5 \pm 4,49 \mathrm{~cm}$ \\
\hline $378 / 2$ & žena & - & $17-20$ & \\
\hline
\end{tabular}

Tab. 1. Shrnutí základního antropologického určení.

\begin{tabular}{|c|c|c|c|c|c|c|c|c|c|c|c|c|c|c|c|c|}
\hline \multirow{3}{*}{$\underbrace{\text { Kost }}_{\text {Objekt }} \quad$ Míra } & \multicolumn{14}{|c|}{ Femur } & \multirow{2}{*}{\multicolumn{2}{|c|}{$\begin{array}{c}\text { Tibia } \\
\text { M1 }\end{array}$}} \\
\hline & \multicolumn{2}{|c|}{ M1 } & \multicolumn{2}{|c|}{ M6 } & \multicolumn{2}{|c|}{ M7 } & \multicolumn{2}{|c|}{ M8 } & \multicolumn{2}{|c|}{ M18 } & \multicolumn{2}{|c|}{ M19 } & \multicolumn{2}{|c|}{ M20 } & & \\
\hline & $\mathrm{dx}$ & $\sin$ & $\mathrm{dx}$ & $\sin$ & $\mathrm{dx}$ & $\sin$ & $\mathrm{dx}$ & $\sin$ & $\mathrm{dx}$ & $\sin$ & $\mathrm{dx}$ & $\sin$ & $\mathrm{dx}$ & $\sin$ & $\mathrm{dx}$ & $\sin$ \\
\hline 323 & 361 & 359 & - & - & - & - & - & - & - & - & - & - & - & $\begin{array}{c}- \\
\end{array}$ & 310 & 309 \\
\hline 358 & - & $\begin{array}{llll}- & & & \end{array}$ & - & - & - & - & - & - & - & - & - & - & - & - & $\begin{array}{ll}- \\
\end{array}$ & 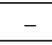 \\
\hline 359 & 508 & - & 35 & - & 28 & - & 97 & - & - & 51 & 51 & 52 & - & 164 & 409 & 409 \\
\hline 360 & 362 & 360 & $\begin{array}{llll}- & & & \\
\end{array}$ & - & $\begin{array}{ccc}- \\
\end{array}$ & - & $\begin{array}{ccc}- \\
-\end{array}$ & - & - & $\begin{array}{c}- \\
\end{array}$ & 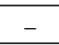 & $\begin{array}{llll}- & & & 0 \\
\end{array}$ & - & - & - & $\begin{array}{llll}- & & & 0\end{array}$ \\
\hline 377 & - & - & - & 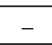 & 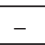 & 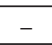 & - & - & - & 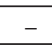 & 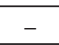 & - & - & - & 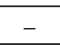 & 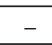 \\
\hline $378 / 1$ & 402 & 404 & - & $\begin{array}{l}- \\
\end{array}$ & $\begin{array}{l}- \\
-\end{array}$ & $\begin{array}{l}- \\
-\end{array}$ & - & - & - & $\begin{array}{l}- \\
\end{array}$ & $\begin{array}{l}- \\
\end{array}$ & $\begin{array}{l}- \\
-\end{array}$ & - & - & 350 & - \\
\hline $378 / 2$ & 460 & - & 26 & - & 23 & - & 77 & - & 42 & - & 43 & - & 136 & - & 368 & - \\
\hline
\end{tabular}

Tab. 2. Metrické shrnutí (kosti dolní končetiny; údaje v mm).

\begin{tabular}{|l|c|c|c|c|c|c|}
\hline \multirow{2}{*}{ Kost } & \multicolumn{2}{|c|}{ Humerus } & \multicolumn{2}{c|}{ Radius } & \multicolumn{2}{c|}{ Ulna } \\
\hline \multirow{2}{*}{ Objekt } & \multicolumn{2}{|c|}{ M1 } & \multicolumn{2}{c|}{ M1 } & \multicolumn{2}{c|}{ M1 } \\
\cline { 2 - 7 } & $\mathrm{dx}$ & sin & $\mathrm{dx}$ & $\sin$ & $\mathrm{dx}$ & $\sin$ \\
\hline 323 & 268 & 266 & - & - & - & - \\
\hline 358 & - & - & - & - & - & - \\
\hline 359 & 345 & 343 & 274 & - & 298 & - \\
\hline 360 & 260 & - & 200 & - & - & - \\
\hline 377 & - & - & - & - & - & - \\
\hline $378 / 1$ & 300 & - & 215 & 213 & 238 & 238 \\
\hline $378 / 2$ & - & - & - & - & - & - \\
\hline
\end{tabular}

Tab. 3. Metrické shrnutí (kosti horní končetiny; údaje v mm).

zubní kámen na labiální ploše horních i dolních řezáků (u 5 jedinců) a Schmorlovy uzly na dolní terminální ploše Th4 až Th7 u dospělého muže (objekt 359). Jedná se pravděpodobně o projev deformační spondylózy (spondylosis deformans). I když dle nejnovějších poznatků začínají někteří autoři řadit Schmorlovy uzly ke geneticky podmíněným anatomickým varietám (např. Gali Dar a Israel Hershkovitz). V hrobě v objektu 379 nebyly nalezeny žádné lidské kosti, pouze zlomek pánevní kosti většího zviŕ̌ete. Dosavadní genetické analýzy jednoznačně nepotvrdily př́ibuznost jedincủ, ale také ji zatím nevyvrátily. Jelikož archeologické zpracování nálezů prozatím neproběhlo (není tedy $\mathrm{k}$ dispozici prèsnější datace nálezu), není zatím možné provést srovnání s jinými populacemi z daného období a kulturního zařazení.

\section{LITERATURA}

Acsádi, György - Nemeskéri, János (1970): History of human life span and mortality. Budapest: Akadémiai Kiadó.

Aufderheide, Arthur C. - Rodríguez-Martin, Conrado (1998): The Cambridge Encyclopedia of Human Paleopathology. Cambridge: Cambridge University Press.

Černý, Milan - Komenda, Stanislav (1980): Sexual Diagnosis by the Measurements of Humerus and Femur. Sborník prací pedagogické fakulty Univerzity Palackého v Olomouci-Biologie, 2, 147-167.

Horáčková, Ladislava - Strouhal, Eugen - Vargová, Lenka (2004): Základy paleopatologie. In: Malina, Jaroslav, ed., Panoráma biologické a sociokulturní antropologie: Modulové učební texty pro studenty antropologie a „př́buzných“ oborů, 15. svazek. Edice Scientia Nadace Universitas Masarykiana. Brno: Akademické nakladatelství CERM - Masarykova univerzita v Brně - Nakladatelství a vydavatelství NAUMA.

Lovejoy, Owen C. (1985): Dental Wear in the Libben Population: Its Functional Pattern and Role in the Determination of Adult Skeletal Age at Death. American Journal of Physical Anthropology, 68, 47-56.

Ortner, Donald J. - Putschar, Walter G. J. (1985): Identification of Pathological Conditions on Human Skeletal Remains. Washington: Smithsonian Institution Press.

Martin, Rudolf - Saller, Karl (1957): Lehrbuch der Anthropologie in systematischer Darstellung. Stuttgart: Gustav Fischer Verlag.

Novotný, Vladimír - İşcan, Mehmet Yaşar - Loth, Susan R. (1993): Morphologic and Osteometric Assessment of age, Sex and Race from the Skull. In: Mehmet Yaşar İşcan, Richard P. Helmer, eds., Forensic Analysis of the Skull: Craniofacial Analysis, Reconstruction, and Identification. New York: John Wiley \& Sons Inc. 71-88.

Schaefer, Maureen - Black, Sue - Scheuer, Louise (2009): Juvenile Osteology: A Laboratory and Field Manual. Amsterdam; Burlington, MA: Elsevier.

Schutkowski, Holger (1993): Sex Determination of Infant and Juvenile skeletons I. Morphognostic Features. American Journal of Physical Anthropo$\log y, 90,199-205$.

Sjøvold, Torstein (1990): Estimation of Stature from Long Bones Utilizing the Line of Organic Correlation. Human Evolution, 5, 431-447.

Stloukal, Milan - Hanáková, Hana (1978): Die Länge der Langsknochen altslawischer Bevölkerungen unter besonderer Berucksichtigung von Wachstumsfragen. Homo, 29 (1), 53-69.

Stloukal, Milan et al. (1999): Antropologie. Př́ručka pro studium kostry. Praha: Národní muzeum.

Ubelaker, Douglas H. (1978): Human Skeletal Remains: Excavation, Analysis and Interpretation. Washington, DC: Smithsonian Institute Press. 


\section{AUTORKA}

Beran-Cimbůrková, Petra (13. 7. 1980), fyzická antropoložka, absolventka Ústavu antropologie Prŕrodovědecké fakulty Masarykovy univerzity. Diplomová práce: Antropologický rozbor kosterního materiálu z krypty kostela svatého Mikuláše ve Znojmě (2004). Připra- vovaná disertační práce: Pohřebiště v Mladé Boleslavi v kontextu pohřebního ritu 10.-12. století.

Kontakt: Mgr. Petra Beran-Cimbůrková, Ústav archeologické památkové péče středních Čech, Praha, Nad Olšinami 3/448, 100 00, Praha10, e-mail: petra.cimburkova@uappsc.cz 
